\title{
Phenotypic Characteristics and Function of NK Cell Subsets in cART-Treated HIV-1-Infected Individuals
}

\author{
Manthana Mitchai ${ }^{1,2}$, Niramon Leeratanapetch ${ }^{3}$, Viraphong Lulitanond ${ }^{4}$, \\ Pattaravadee Srikoon ${ }^{2}$, Shinichiro Hattori' ${ }^{2}$, Kulthida Vaeteewoottacharn ${ }^{2,5}$, \\ Sopit Wongkham ${ }^{5}$, Seiji Okada ${ }^{2 *}$ \\ ${ }^{1}$ Department of Clinical Pathology, Khon Kaen Hospital, Khon Kaen, Thailand \\ ${ }^{2}$ Division of Hematopoiesis, Center for AIDS Research, Kumamoto University, Kumamoto, Japan \\ ${ }^{3}$ Department of Internal Medicine, Khon Kaen Hospital, Khon Kaen, Thailand \\ ${ }^{4}$ Department of Microbiology, Faculty of Medicine, Khon Kaen University, Khon Kaen, Thailand \\ ${ }^{5}$ Department of Biochemistry, Faculty of Medicine, Khon Kaen University, Khon Kaen, Thailand \\ Email: *kadas@kumamoto-u.ac.jp
}

Received 19 June 2014; revised 15 July 2014; accepted 8 August 2014

Copyright (C) 2014 by authors and Scientific Research Publishing Inc.

This work is licensed under the Creative Commons Attribution International License (CC BY). http://creativecommons.org/licenses/by/4.0/

(c) (i) Open Access

\section{Abstract}

Natural killer (NK) cell plays an important role in an innate immune response against viral infection. The kinetics regulation and functional consequences of NK cells in the pathogeneses of diseases are uncertain. We analyzed NK cell distribution and function of successfully combination antiretroviral therapy (cART)-treated HIV-1 infected individuals in Khon Kaen Regional Hospital, Thailand. The results demonstrated that increased percentage and the total number of NK cell in cART-treated HIV-1 infected patients with preferential high levels of CD56 ${ }^{\mathrm{dim}} \mathrm{CD}^{16}{ }^{+}$and $\mathrm{CD}^{-} 6^{-} \mathrm{CD}^{-} 6^{+}$ subsets when compared with a control group even in undetectable viral load ( $<40$ copies per milliliter). Concomitantly, decreased cytotoxic activity measured by CD107a surface expression with maintained IFN- $\gamma$ production implied the impairment of cytolytic activity was not recovered after cART treatment. Thus, altered NK cell frequency and function by HIV-1 infection are not completely recovered with cART, which may contribute to impaired cellular immune response and persistence of HIV-1.

\section{Keywords}

HIV-1, Combination Antiretroviral Therapy (cART), Natural Killer Cells, IFN- $\gamma$, CD107a, Cytotoxic Activity, Cytokine Production

*Corresponding author. 


\section{Introduction}

Natural killer (NK) cells are large lymphocytes functioning in the innate immune response against viral infection and tumors, and modulation of the subsequent adaptive immune response through their cytokine production and cytotoxicity [1]. The NK population consists of approximately 5\% - 15\% of peripheral blood mononuclear cells. Human NK subsets are defined by the absence of CD3 expression and the expressions of CD56 and/or CD16. NK cells are classified into 4 subsets based on marker expressions and functions [2] [3]: The major NK cell subset is $\mathrm{CD} 56^{\mathrm{dim}} \mathrm{CD} 16^{+}$with cytolytic activity; the second subset, CD56 ${ }^{\text {bright }}$, secretes cytokines; the third subset, $\mathrm{CD}^{-} 6^{-} \mathrm{CD} 16^{+}$, is rarely detected in healthy adults but extensively observed in cord blood; and the last subset, CD56 ${ }^{\mathrm{dim}} \mathrm{CD} 16^{-}$, is functionally unclear but seems to respond to tumor cell-stimulated degranulation [4]. NK cell subset alteration in virus-infected individuals has been previously demonstrated, suggesting the functional significance of the NK subset in disease progression. The current study focused on human immunodeficiency virus-1 (HIV-1) infection. Even though the role of NK cells in the course of HIV-1 infection remains to be elucidated, it was recently well documented that NK cells isolated from HIV-1-infected individuals are impaired in their ability to kill HIV-1-infected cells as well as tumor cells [5] [6]. Numerous studies have characterized the effects of HIV viremia on NK cell phenotype and function. Expansion of the CD56 ${ }^{-} \mathrm{CD}_{16}{ }^{+}$subset as well as depletion of $\mathrm{CD}{ }^{\mathrm{dim}} \mathrm{CD} 16^{+}$has been demonstrated in viremic individuals [7] [8]. The CD56 ${ }^{-} \mathrm{CD} 16^{+}$subset becomes more prominent in active virally replicated subsets at the expense of CD56 $6^{\text {bright }}$ and CD56 ${ }^{-}$CD16 ${ }^{+}$NK cells [9] [10]. It is likely that the redistribution of NK subsets may contribute to the observed loss of NK cell function over the course of HIV-1 infection.

Human immunodeficiency virus type 1 (HIV-1) causes a persistent infection in human immune competent cells that is ultimately associated with the development of acquired immune deficiency syndrome (AIDS). Around 35.3 million people are infected with this virus worldwide, with approximately 1.6 million deaths occurring per year due to AIDS. Since the discovery, AIDS has caused an estimated 36 million deaths worldwide [11]. Thus, AIDS is the life-threating pandemic disease that has had a great impact on society as an illness, as a source of discrimination, and as economics [12]. Treatment with combination antiretroviral therapy (cART) has obviously reduced the risk of AIDS development and death. However, despite efficient treatment with cART in the suppression of viral replication, HIV-1-infected individuals still had higher risks of morbidity and mortality than the uninfected population [13]. Moreover, because patients live longer, non-AIDS-related disorders are becoming significant, not only among those with impaired immune responses, but also among those with higher $\mathrm{CD}^{+}$cell counts [14]. Thus, the incomplete immune recovery of innate immunity including NK cells is speculated for disease progression [15].

The present study analyzed the phenotypic and functional characteristics of NK cells from cART-treated individuals. It was found that $\mathrm{CD} 56^{\mathrm{dim}} \mathrm{CD} 16^{+}$as well as $\mathrm{CD} 56^{-} \mathrm{CD} 16^{+}$subsetswere significantly increased in patients; however, cytotoxic activity was not recovered even after cART. These data suggested that the impairment of NK function may contribute to decreased total immune function in cART-treated individuals.

\section{Methodology}

\subsection{Study and Subjects}

Peripheral blood samples were obtained from sixteen HIV-1-infected individuals attending the ARV clinic, Department of Internal Medicine, Khon Kean Hospital. Patients were treated with cART for at least 1 year and had an undetectable viral load ( $<40$ copies per milliliter). Twelve age-matched HIV-1 seronegative subjects who visited the Department of Internal Medicine, Khon Kean Hospital were selected as controls (Table 1). The study was approved by the Ethics Committee of Khon Kaen Regional Hospital, Khon Kaen, Thailand. All samples were collected with written informed consent.

\subsection{Cell Separation and Culture Stimulation with K562 Cell Line}

Peripheral blood mononuclear cells (PBMC) were isolated from heparinized blood by Ficoll-Hypaque gradient centrifugation. The MHC class I-devoid erythroleukemic cell line, K562 (obtained from RIKEN Cell Bank, Tsukuba, Japan), was cultured in RPMI1640 medium (Wako Chemical, Osaka, Japan) supplemented with $10 \%$ fetal bovine serum (FBS) (Hyclone, UT, USA), 100 U/mL penicillin (Meiji Seika Pharma, Tokyo, Japan) and $100 \mu \mathrm{g} / \mathrm{mL}$ streptomycin (Wako Chemical). 
A

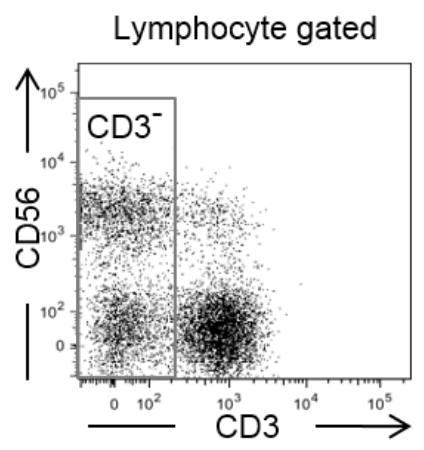

B

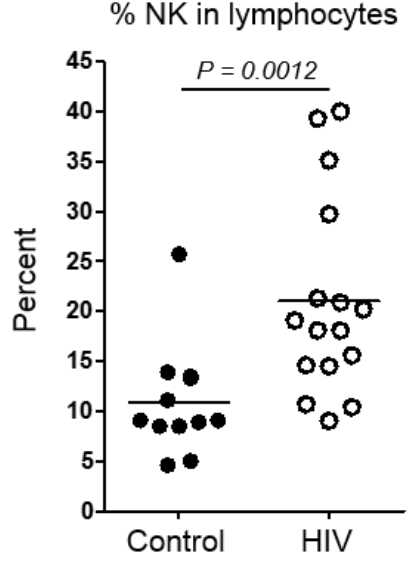

$\mathrm{CD}^{-}$gated

NK subset gating

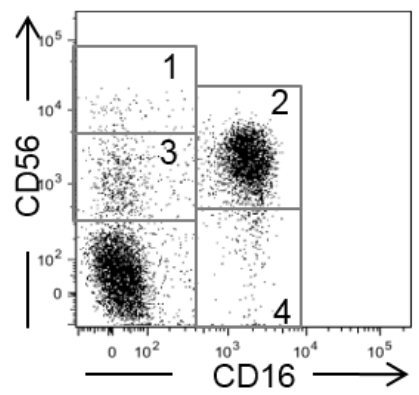

C

Total NK in PBMC

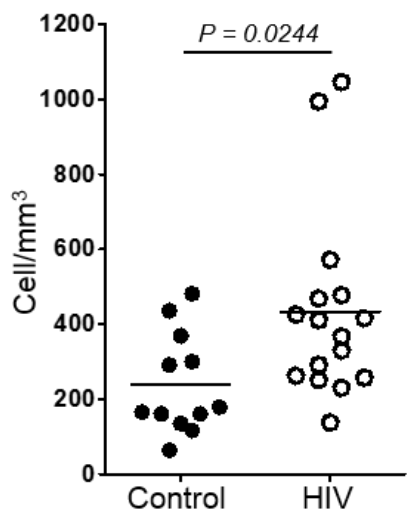

D

NK subset in PBMC

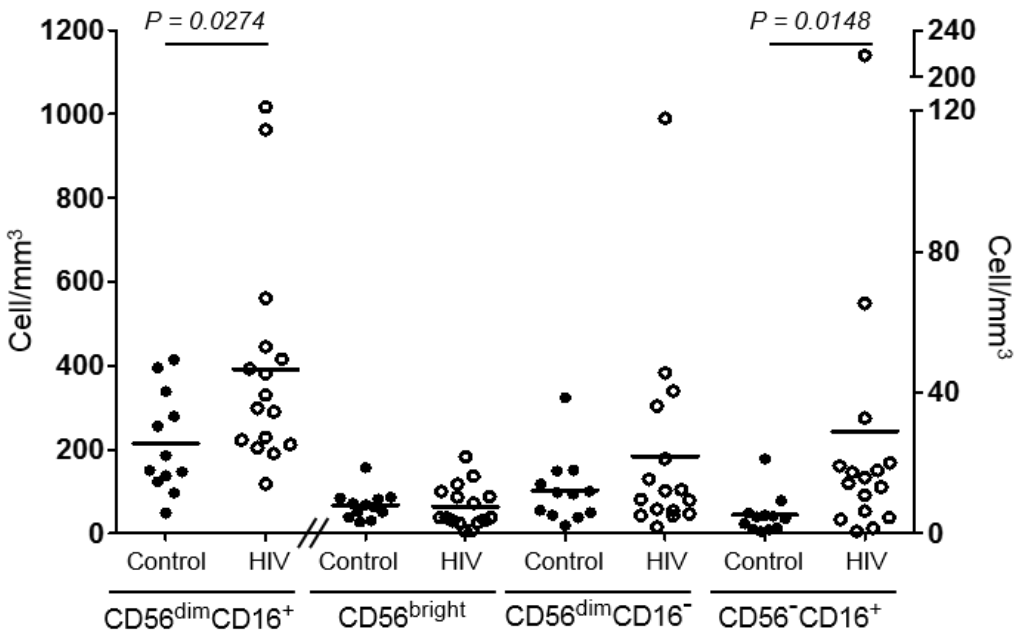

Figure 1. Frequency and absolute number of NK cells in cART-treated HIV-infected individuals. (A) Total NK cells were selected by CD3-negative (CD3 ${ }^{-}$) lymphocyte gating followed by determining CD56 and CD16 expression. CD56 CD16 population was excluded and 4 NK cell subsets, 1) CD56 bright, 2) CD56 ${ }^{\mathrm{dim}} \mathrm{CD} 16^{+}$, 3) CD56 ${ }^{\mathrm{dim}} \mathrm{CD} 16^{-}$and 4$) \mathrm{CD}^{2} 6^{-} \mathrm{CD} 16^{+}$, were divided; (B) Total NK cell percentage in lymphocytes; (C) Absolute number of NK cells in PBMC; (D) Absolute NK subpopulation numbers in PBMC. CD56 ${ }^{\mathrm{dim}} \mathrm{CD} 16^{+}$subset is plotted against the left $\mathrm{Y}$-axis and the other subsets are plotted against the right $\mathrm{Y}$-axis. Plots show the results in healthy controls $(\mathrm{n}=12$, closed circles) and cART-treated HIV-1-infected individuals ( $n=16$, open circles). Bars in A-C represent the means. 


\subsection{Phenotypic Analysis of PBMC by Flow Cytometry}

The following antibodies were used in the current study: CD3-PECy7 (UCHT1) from eBioscience (San Diego, CA); CD56-APC (NKH-1) from Beckman Coulter (Paris, France); CD16-Pacific Blue (3G8) from Biolegend (San Diego, CA); CD107a-PE (H4A3), and anti-IFN- $\gamma$ FITC (4S.B3) from BD Pharmingen (San Diego, CA). For surface staining, cells were stained and incubated for $30 \mathrm{~min}$ on ice protected from light. For intracellular staining, cells were then washed in FACS washing medium (Phosphate buffered saline (PBS) containing 3\% FBS and $0.1 \% \mathrm{NaN}_{3}$ ), fixed with $4 \%$ paraformaldehyde, washed and permeabilized using $0.1 \%$ Saponin (Sigma), and then stained for IFN- $\gamma$ production. Stained cells were fixed with $4 \%$ paraformaldehyde, and analyzed by LSRII flow cytometry (BD Bioscience, San Jose, CA) and FlowJo software (Tree Star, San Carlos, CA).

\subsection{Degradation and Intracellular Cytokine Production Analysis}

PMBCs and K562 cells were co-cultured at effect or to target ratio of 10:1. Cells were cultured for 1 hour in a 5\% $\mathrm{CO}_{2}$ incubator, after which bredfeldin A (10 $\mu \mathrm{g} / \mathrm{ml}$; Sigma, St. Louis, MO) was added to block cytoplasmic protein transportation, incubated for an additional 5 hours, then cells were stained for surface markers and intracellular IFN- $\gamma$ [16] [17]. Stained cells were fixed with $4 \%$ paraformaldehyde and permeabilized with $0.1 \%$ saponin, and then analyzed by flow cytometry.

\subsection{Statistical Analysis}

GraphPad Prism software (GraphPad Software, Inc., La Jolla, CA, USA) was used with the non-parametric Mann-Whitney $\mathrm{U}$ test to analyze the difference between 2 groups. $P<0.05$ was considered significant.

\section{Results}

\subsection{Clinical Characteristics}

Sixteen cART-treated HIV-1-infected patients with an undetectable viral load ( $<40$ copies per milliliter) and 12 controls were recruited for this study. Fifty percent of patients and $42 \%$ of controls were male. The average ages of patient and control groups were $33.1 \pm 6.5$ and $26.5 \pm 11.7$ years, respectively. The clinical characteristics of cART-treated HIV-1-infected and control subjects are shown in Table 1. In cART-treated HIV-1-infected patients, the average white blood cell counts (WBC), \% lymphocytes, total CD4 and \% CD4 were $6.919 \% \pm 2.461 \%$ $\times 10^{9} / \mathrm{L}, 32 \% \pm 9.3 \%, 39 \% \pm 4 \%$ and $0.765 \pm 0.197 \times 10^{9} / \mathrm{L}$ while there were $6.509 \pm 2.014 \times 10^{9} / \mathrm{L}, 32.0 \% \pm$ $6.2 \%, 17 \% \pm 8.1 \%$ and $0.351 \pm 0.199 \times 10^{9} / \mathrm{L}$ in controls. There was no difference in WBC count and \% lymphocytes between the 2 groups but total CD4 count and \% CD4 were significant lower in cART-treated HIV-1infected individuals.

\subsection{Total NK and CD56-16+ NK Subsets Are Increased in cART-Treated HIV-1-Infected Individuals}

We compared NK cells between the 2 subject groups. NK cell gating is demonstrated in Figure 2(A). The NK cell percentages of cART-treated HIV-1-infected individuals and controls were $21.04 \% \pm 9.89 \%$ and $10.93 \% \pm$ 5.54\%, respectively (Figure 1(A) and Figure 1(B)). Absolute NK cell numbers of cART-treated HIV-1-infected individuals were $0.433 \pm 0.254 \times 10^{9} / \mathrm{L}$ and of controls were $0.238 \pm 0.134 \times 10^{9} / \mathrm{L}$ (Figure $1(\mathrm{C})$ ). Both the percentage and absolute numbers of total NK cells were significantly higher in cART-treated HIV-1-infected indi-

Table 1. Description of cART-treated HIV-1-infected patients and control subjects enrolled in this study.

\begin{tabular}{cccc}
\hline & Control $(\mathbf{n}=\mathbf{1 2})$ & $\begin{array}{c}\text { cART-Treated HIV-1-Infected Patients } \\
(\mathbf{n}=\mathbf{1 6})\end{array}$ & $\begin{array}{c}\text { P-Value } \\
\text { WBC count }\left(\times 10^{9} / \mathrm{L}\right)\end{array}$ \\
$\begin{array}{c}\text { \% Lymphocytes } \\
\text { \% CD4 }\end{array}$ & $31.7 \pm 6.4$ & $6.919 \pm 2,461$ & 0.626 \\
\hline CD4 count $\left(\times 10^{9} / \mathrm{L}\right)$ & $33.8 \pm 4$ & $31.8 \pm 9.3$ & $17.3 \pm 8.1$ \\
\hline
\end{tabular}


viduals group $(P=0.0012$ and $P=0.0244)$. When NK subset distribution was determined, $\mathrm{CD} 56^{\mathrm{dim}} \mathrm{CD} 16^{+}$, CD56 ${ }^{\text {bright }}$, CD56 ${ }^{\text {dim }} \mathrm{CD} 16^{-}, \mathrm{CD}^{-} 6^{-} \mathrm{CD}_{16}{ }^{+}$of cART-treated HIV-1-infected individuals were $0.392 \pm 0.259$, $0.008 \pm 0.006,0.022 \pm 0.029$ and $0.029 \pm 0.053 \times 10^{9} / \mathrm{L}$, respectively, and there were $0.215 \pm 0.120,0.008 \pm$ $0.004,0.012 \pm 0.010$ and $0.005 \pm 0.006 \times 10^{9} / \mathrm{L}$ in controls. Thus, significantly increased CD56 $6^{\mathrm{dim}} 16^{+}$and $\mathrm{CD}^{-} 16^{+}$subsets were observed in cART-treated HIV-1-infected individuals $(P=0.0274$ and $P=0.0148)$ (Figure 1(D)).

\subsection{Impaired Cytotoxic Function of NK Cells during HIV-1 Infection}

NK functions in each subset were determined by the detection of CD107a expression and IFN- $\gamma$ production after stimulation with MHC-class I devoid K562. CD107a is a degranulation marker which represents cytotoxic function [17]. CD107a was detected in $11.91 \% \pm 4.93 \%$ of cART-treated HIV-1-infected patients and $27.22 \% \pm$ 20.04\% of controls after K562 stimulation. It was significantly decreased in cART-treated HIV-1-infected individuals $(P=0.0009$ ) (Figure $2(\mathrm{~A})$ and Figure $2(\mathrm{C})$ ) whereas IFN- $\gamma$ production was maintained (Figure 2(B) and Figure 2(D)) in cART-treated HIV-1 infected individuals when compared to controls $(6.71 \% \pm 4.97 \%$ vs. $8.45 \% \pm 7.82 \%, P=0.3579$ ).

\section{Discussion}

In this study, we focused on the phenotypic characteristics of NK subsets and their functions in cART-treated HIV-1-infected individuals. cART-treated individuals with an undetectable viral load ( $<40$ copies per milliliter) were recruited and cytotoxic and cytokine release functions were determined with surface CD107a expression and IFN- $\gamma$ production. The results showed that in cART-treated individuals, total NK cells, CD56 ${ }^{\mathrm{dim}} \mathrm{CD} 16^{+}$and $\mathrm{CD}_{6}{ }^{-} \mathrm{CD} 16^{+} \mathrm{NK}$ subsets were increased. Although the primary cytotoxic NK subset, CD56 ${ }^{\mathrm{dim}} \mathrm{CD} 16^{+}$, was expanded, the cytotoxic function demonstrated by CD107a expression was suppressed in NK cells from cARTtreated individuals.

With the introduction of cART, the incidence of opportunistic infection and the occurrence of AIDS-defining malignancies have markedly decreased due to improved immunological function; however, the incidence of nonAIDS-defining malignancies (e.g. lung cancer and Hodgkin lymphoma) is increasing and becoming a major cause of death in cART-treated HIV-1-infected individuals [18]. This could be partially explained by the incomplete recovery of NK cell function. In the current study, phenotypic analysis of NK cells subsets demonstrated significant increases of NK cells in both percentage and absolute number in cART-treated individuals (Figure 1). Among the NK cell subsets, $\mathrm{CD} 56^{\mathrm{dim}} \mathrm{CD} 16^{+}$and $\mathrm{CD} 56^{-} \mathrm{CD} 16^{+}$anergic NK subsets were increased whereas no significant differences were detected in the others. These data suggested that NK cells were expanded with preferential increases of $\mathrm{CD} 56^{\mathrm{dim}} \mathrm{CD} 16^{+}$and $\mathrm{CD}^{-} 6^{-} \mathrm{CD} 16^{+}$subsets during HIV-1 infection and remained increased even after cART therapy, in agreement with previous studies [19] [20]. In contrast, CD107a expression but not IFN- $\gamma$ production was suppressed in cART-treated individuals (Figure 2). This functional suppression might be due to the redistribution of NK subsets in cART-treated individuals. Impaired NK functions during HIV-1 infection have been documented. HIV-1 viremia induces several phenotypic and functional abnormalities in NK cells [21]-[23]. Expansion of a highly dysfunctional $\mathrm{CD} 56^{-} \mathrm{CD} 16^{+}$subset in HIV viremic individuals is known to impair the function of the total NK population [8]. Our study suggested that the dysfunctional CD56 ${ }^{-} \mathrm{CD} 16^{+}$subset remains even after cART treatment until viremia reaches an undetectable level. Hence, HIV-1 affects the NK subset distribution as well as functioning independently of viral load.

It has been shown that administration of IL-2 together with cART augments the number and function of NK cells as well as $\mathrm{CD}^{+} \mathrm{T}$ cells [24]. The augmented function of NK cells was also demonstrated with IL-7 and IL-15 in an animal model [15] and IL-21 in vitro [25]. This cytokine-supporting therapy is expected to enable complete recovery of the immune system including NK cell function in cART-treated HIV-1-infected individuals, which may contribute to the suppression of remaining HIV-1 and the onset of malignancies.

\section{Conclusion}

In conclusion, our findings showed that total NK cell number and a dysfunctional $\mathrm{CD}^{-} 6^{-} \mathrm{CD} 16^{+}$subset were not recovered even after cART treatment. Cytotoxic function but not IFN- $\gamma$ was also kept impaired after cART treatment. Cytokine supplementation therapy inducing the modulation of NK function may change the clinical 
A

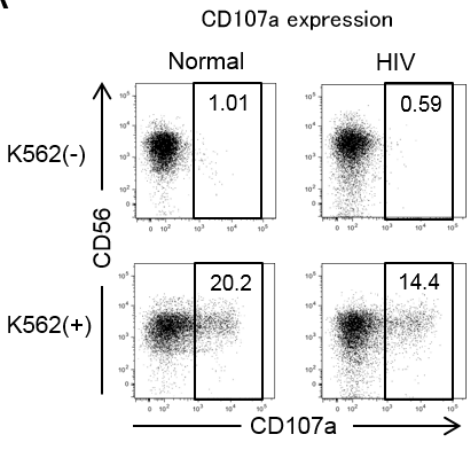

C

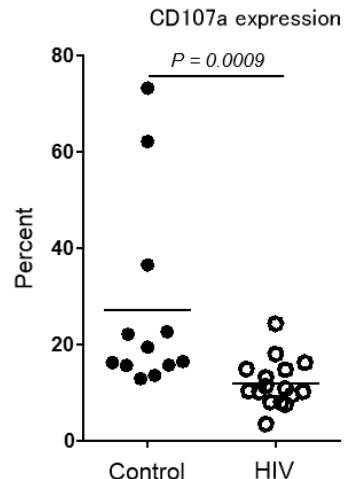

B

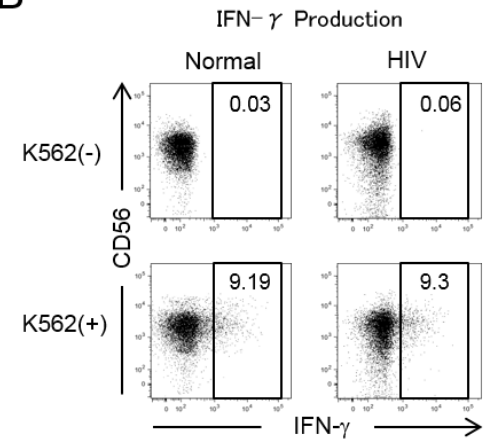

D

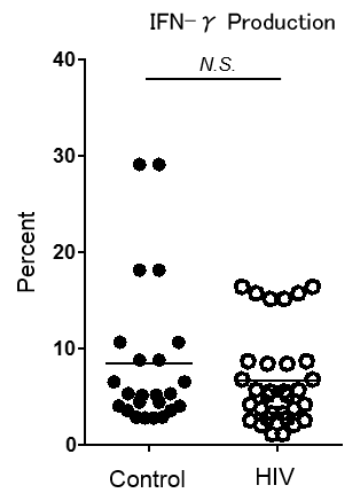

Figure 2. Expression of a CD107a degradation marker and IFN- $\gamma$ by NK cells in cART-treated HIV-infected individuals. (A) (B) Dot plots showing gated NK cell expression of CD107a and IFN- $\gamma$ with or without stimulation with K562; (C) (D) Percentages of CD107a and IFN- $\gamma$ positive NK cells. Plots show the results in healthy controls $(\mathrm{n}=12$, closed circles) and cART-treated HIV-infected individuals ( $\mathrm{n}=16$, open circles). Bars represent the means. (N.S.: not significant).

fate and prognosis of HIV-1-infected individuals [5] [26]-[28]. Further studies are needed to elucidate the molecular mechanism of HIV-1 infection-induced NK dysfunction.

\section{Acknowledgements}

We are grateful to Ms. Ikuko Suzu for technical assistance and Ms. Kyoko Tokunaga for secretarial assistance. This study was supported by the RONPAKU Program from the Japan Society of the Promotion of Science (JSPS), a Health and Labour Sciences Research Grant from the Ministry of Health, Labour, and Welfare of Japan (H25-AIDS-I-002), and the Tokyo Biochemical Research Foundation.

\section{Authors Contributions}

Conceived and designed of experiment: MM, VL, SW, SO; performed the experiment: MM, NL, PS, SH; analyzed the data: MM, KV, SO; wrote the paper: MM, KV, SO; reviewed the manuscript: VL, SW.

\section{Ethical Approval}

Ethical approval for the main study was obtained from ethical review committee for Khon Kaen Hospital, Kumamoto University and Khon Kaen University. Written informed consent was obtained from each participant prior to the study initiation.

\section{Competing Interest}

The authors declare that there is no financial or personal relationship(s) that may have inappropriately influenced the writing of this article. 


\section{References}

[1] Lodoen, M.B. and Lanier, L.L. (2006) Natural Killer Cells as an Initial Defense against Pathogens. Current Opinion in Immunology, 18, 391-398. http://dx.doi.org/10.1016/j.coi.2006.05.002

[2] Cooper, M.A., Fehniger, T.A. and Caligiuri, M.A. (2001) The Biology of Human Natural Killer-Cell Subsets. Trends in Immunology, 22, 633-640. http://dx.doi.org/10.1016/S1471-4906(01)02060-9

[3] Caligiuri, M.A. (2008) Human Natural Killer Cells. Blood, 112, 461-469. http://dx.doi.org/10.1182/blood-2007-09-077438

[4] Penack, O., Gentilini, C., Fischer, L., Asemissen, A.M., Scheibenbogen, C., Thiel, E. and Uharek, L. (2005) CD56 ${ }^{\text {dim }}$ CD16 ${ }^{\text {neg }}$ Cells Are Responsible for Natural Cytotoxicity against Tumor Targets. Leukemia, 19, 835-840. http://dx.doi.org/10.1038/sj.leu.2403704

[5] Alter, G. and Altfeld, M. (2009) NK Cells in HIV-1 Infection: Evidence for Their Role in the Control of HIV-1 Infection. Journal of Internal Medicine, 265, 29-42. http://dx.doi.org/10.1111/j.1365-2796.2008.02045.x

[6] Naranbhai, V., Altfeld, M., Karim, S.S., Ndung'u, T., Karim, Q.A. and Carr, W.H. (2013) Changes in Natural Killer Cell Activation and Function during Primary HIV-1 Infection. PLoS ONE, 8, Article ID: e53251. http://dx.doi.org/10.1371/journal.pone.0053251

[7] Alter, G., Teigen, N., Davis, B.T., Addo, M.M., Suscovich, T.J., Waring, M.T., Streeck, H., Johnston, M.N., Staller, K.D., Zaman, M.T., Yu, X.G., Lichterfeld, M., Basgoz, N., Rosenberg, E.S. and Altfeld, M. (2005) Sequential Deregulation of NK Cell Subset Distribution and Function Starting in Acute HIV-1 Infection. Blood, 106, 3366-3369. http://dx.doi.org/10.1182/blood-2005-03-1100

[8] Mavilio, D., Lombardo, G., Benjamin, J., Kim, D., Follman, D., Marcenaro, E., O’Shea, M.A., Kinter, A., Kovacs, C., Moretta, A. and Fauci, A.S. (2005) Characterization of CD56 $/$ CD $16^{+}$Natural Killer (NK) Cells: A Highly Dysfunctional NK Subset Expanded in HIV-Infected Viremic Individuals. Proceedings of National Academy of Science of the Unite States of America, 102, 2886-2891. http://dx.doi.org/10.1073/pnas.0409872102

[9] Mavilio, D., Lombardo, G., Kinter, A., Fogli, M., La Sala, A., Ortolano, S., Farschi, A., Follmann, D., Gregg, R., Kovacs, C., Marcenaro, E., Pende, D., Moretta, A. and Fauci, A.S. (2006) Characterization of the Defective Interaction between a Subset of Natural Killer Cells and Dendritic Cells in HIV-1 Infection. Journal of Experimental Medicine, 203, 2339-2350. http://dx.doi.org/10.1084/jem.20060894

[10] Alter, G., Malenfant, J.M., Delabre, R.M., Burgett, N.C., Yu, X.G., Lichterfeld, M., Zaunders, J. and Altfeld, M. (2004) Increased Natural Killer Cell Activity in Viremic HIV-1 Infection. The Journal of Immunology, 173, 5305-5311. http://dx.doi.org/10.4049/jimmunol.173.8.5305

[11] UNAIDS/World Health Organization (2014) Report on the Global HIV/AIDS Epidemic, 2013. UNAIDS, Geneva. http://www.unaids.org/en/media/unaids/contentassets/documents/epidemiology/2013/gr2013/unaids global report 20 13_en.pdf

[12] Kallings, L.O. (2008) The First Postmodern Pandemic: 25 Years of HIV/AIDS. Journal of Internal Medicine, 263, 218-243. http://dx.doi.org/10.1111/j.1365-2796.2007.01910.x

[13] Bhaskaran, K., Hamouda, O., Sannes, M., Boufassa, F., Johnson, A.M., Lambert, P.C. and Porter, K. (2008) Changes in the Risk of Death after HIV Seroconversion Compared with Mortality in the General Population. JAMA, 300, 51-59. http://dx.doi.org/10.1001/jama.300.1.51

[14] Lau, B., Gange, S.J. and Moore, R.D. (2007) Risk of Non-AIDS-Related Mortality May Exceed Risk of AIDS-Related Mortality among Individuals Enrolling into Care with CD4 ${ }^{+}$Counts Greater than 200 Cells $/ \mathrm{mm}^{3}$. The Journal of Acquired Immune Deficiency Syndromes, 44, 179-187. http://dx.doi.org/10.1097/01.qai.0000247229.68246.c5

[15] Gaardbo, J.C., Hartling, H.J., Gerstoft, J. and Nielsen, S.D. (2012) Incomplete Immune Recovery in HIV Infection: Mechanisms, Relevance for Clinical Care, and Possible Solutions. Clinical and Developmental Immunology, 2012, Article ID: 670957. http://dx.doi.org/10.1155/2012/670957

[16] Dessouki, O., Kamiya, Y., Nagahama, H., Tanaka, M., Suzu, S., Sasaki, Y. and Okada, S. (2010) Chronic Hepatitis C Viral Infection Reduces NK Cell Frequency and Suppresses Cytokine Secretion: Reversion by Anti-Viral Treatment. Biochemical and Biophysical Research Communications, 393, 331-337. http://dx.doi.org/10.1016/j.bbrc.2010.02.008

[17] Alter, G., Malenfant, J.M. and Altfeld, M. (2004) CD107a as a Functional Marker for the Identification of Natural Killer Cell Activity. Journal of Immunological Methods, 294, 15-22. http://dx.doi.org/10.1016/j.jim.2004.08.008

[18] Bonnet, F., Burty, C., Lewden, C., Costagliola, D., May, T., Bouteloup, V., Rosenthal, E., Jougla, E., Cacoub, P., Salmon, D., Chene, G. and Morlat, P. (2009) Changes in Cancer Mortality among HIV-Infected Patients: The Mortalite 2005 Survey. Clinical Infectious Disease, 48, 633-639. http://dx.doi.org/10.1086/596766

[19] Gonzalez, V.D., Falconer, K., Michaelsson, J., Moll, M., Reichard, O., Alaeus, A. and Sandberg, J.K. (2008) Expansion of CD56-NK Cells in Chronic HCV/HIV-1 Co-Infection: Reversion by Antiviral Treatment with Pegylated IF- 
Nalpha and Ribavirin. Clinical Immunology, 128, 46-56. http://dx.doi.org/10.1016/j.clim.2008.03.521

[20] Bjorkstrom, N.K., Ljunggren, H.G. and Sandberg, J.K. (2010) CD56 Negative NK Cells: Origin, Function, and Role in Chronic Viral Disease. Trends in Immunology, 31, 401-406. http://dx.doi.org/10.1016/j.it.2010.08.003

[21] Fauci, A.S., Mavilio, D. and Kottilil, S. (2005) NK Cells in HIV Infection: Paradigm for Protection or Targets for Ambush. Nature Reviews-Immunology, 5, 835-843. http://dx.doi.org/10.1038/nri1711

[22] Hong, H.S., Eberhard, J.M., Keudel, P., Bollmann, B.A., Ahmad, F., Ballmaier, M., Bhatnagar, N., Zielinska-Skowronek, M., Schmidt, R.E. and Meyer-Olson, D. (2010) Phenotypically and Functionally Distinct Subsets Contribute to the Expansion of CD56 $/$ CD16 ${ }^{+}$Natural Killer Cells in HIV Infection. AIDS, 24, 1823-1834. http://dx.doi.org/10.1097/QAD.0b013e32833b556f

[23] Fan, Y.Y., Yang, B.Y. and Wu, C.Y. (2008) Phenotypically and Functionally Distinct Subsets of Natural Killer Cells in Human PBMCs. Cell Biology International, 32, 188-197. http://dx.doi.org/10.1016/j.cellbi.2007.08.025

[24] Mantegani, P., Tambussi, G., Galli, L., Din, C.T., Lazzarin, A. and Fortis, C. (2010) Perturbation of the Natural Killer Cell Compartment during Primary Human Immunodeficiency Virus 1 Infection Primarily Involving the CD56 Bright Subset. Immunology, 129, 220-233. http://dx.doi.org/10.1111/j.1365-2567.2009.03171.X

[25] Strbo, N., de Armas, L., Liu, H., Kolber, M.A., Lichtenheld, M. and Pahwa, S. (2008) IL-21 Augments Natural Killer Effector Functions in Chronically HIV-Infected Individuals. AIDS, 22, 1551-1560. http://dx.doi.org/10.1097/QAD.0b013e3283089367

[26] Streeck, H., Jessen, H., Alter, G., Teigen, N., Waring, M.T., Jessen, A., Stahmer, I., van Lunzen, J., Lichterfeld, M., Gao, X., Allen, T.M., Carrington, M., Walker, B.D., Rockstroh, J.K. and Altfeld, M. (2006) Immunological and Virological Impact of Highly Active Antiretroviral Therapy Initiated during Acute HIV-1 Infection. Journal of Infectious Diseases, 194, 734-739. http://dx.doi.org/10.1086/503811

[27] Alter, G., Teigen, N., Ahern, R., Streeck, H., Meier, A., Rosenberg, E.S. and Altfeld, M. (2007) Evolution of Innate and Adaptive Effector Cell Functions during Acute HIV-1 Infection. Journal of Infectious Diseases, 195, 1452-1460. http://dx.doi.org/10.1086/513878

[28] Michaelsson, J., Long, B.R., Loo, C.P., Lanier, L.L., Spotts, G., Hecht, F.M. and Nixon, D.F. (2008) Immune Reconstitution of CD56 ${ }^{\mathrm{dim}}$ NK Cells in Individuals with Primary HIV-1 Infection Treated with Interleukin-2. Journal of Infectious Diseases, 197, 117-125. http://dx.doi.org/10.1086/524141

\section{Abbreviations}

Acquired Immune Deficiency Syndrome (AIDS)

Combination Antiretroviral Therapy (cART)

Fetal Bovine Serum (FBS)

Human Immunodeficiency Virus-1 (HIV-1)

Peripheral Blood Mononuclear Cells (PBMC)

Phosphate Buffered Saline (PBS)

White Blood Cell Counts (WBC) 
Scientific Research Publishing (SCIRP) is one of the largest Open Access journal publishers. It is currently publishing more than 200 open access, online, peer-reviewed journals covering a wide range of academic disciplines. SCIRP serves the worldwide academic communities and contributes to the progress and application of science with its publication.

Other selected journals from SCIRP are listed as below. Submit your manuscript to us via either submit@scirp.org or Online Submission Portal.
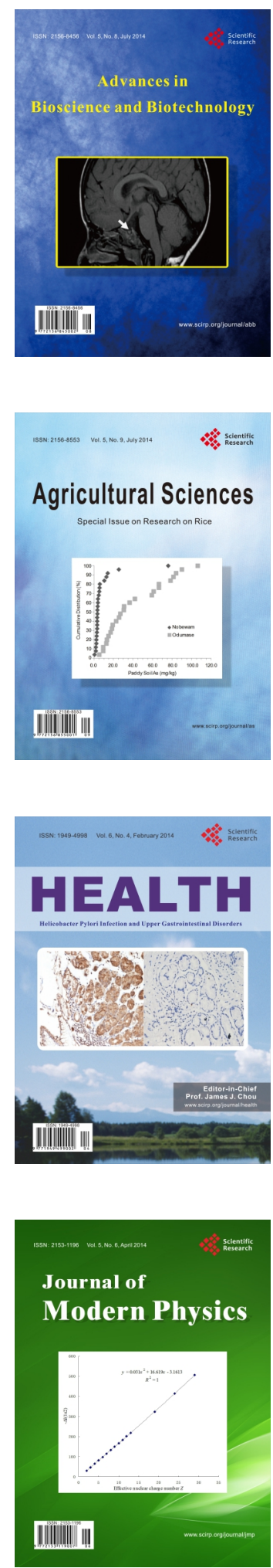
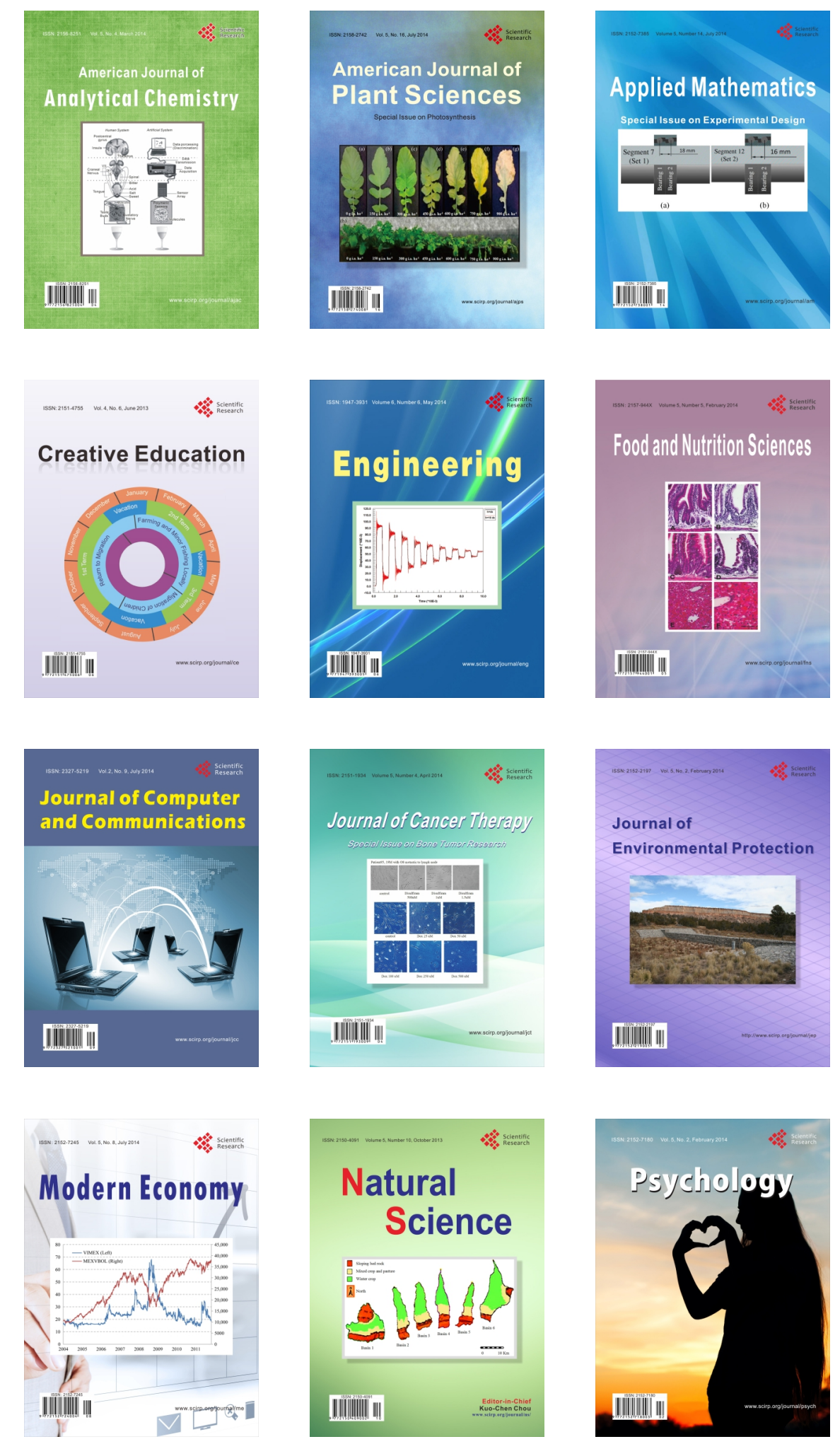